\title{
Dinko Fabris
}

\section{The Role of Solo Singing to the Lute in the Origins of the Villanella alla Napolitana, c. 1530-1570}

\author{
[A Napoli] ... i discepoli poi degl'arteggiani, \\ La sera al tardi accompagnati, o soli, \\ Paion tanti cardelli, o l'uscignoli, \\ Che in queste parti, $\mathrm{e}$ in quelle \\ S'odon cantar nuov'arie, e villanelle \\ Che non si tosto l'havran posti fuori \\ I lor compositori, \\ Che le ritiene a mente \\ Cascun di lor più che perfettamente. \\ Giovan Battista Del Tufo, \\ Ritratto o Modello delle ... delitie e \\ meraviglie della nobilissima Città di \\ Napoli (Ms., 1588)
}

At the beginning of the sixteenth century, Italy and Spain followed parallel and sometimes intersecting paths in the development of secular music forms destined for vocal performance to the accompaniment of a stringed instrument (lute, viola da mano or vihuela). ${ }^{1}$ This phenomenon, unjustly neglected by scholars until recently, manifests itself principally in the Spanish dominions in Italy, particularly the Kingdoms of Naples and Milan and to a certain extent in Rome, thanks to the presence of Spanish popes and cardinals and its role as a centre of Spanish diplomatic activity. In this contribution, I will concentrate on the situation in the capital Naples, summarising and reviewing the information which we have about the birth and significance of the genre of secular vocal music that took its name from the city - the villanella alla napoletana.

The earliest reports of travellers and chroniclers always refer to the Renaissance city as »Napoli gentile«, a magical place of pleasure where all the inhabitants seem to spend their time singing, playing and living happily out of doors. ${ }^{2}$

1 This essay has been conceived by the author as parallel and completing John Griffith's one in this same volume. I would express my gratitude to John Griffiths for his continuing support and suggestions and also to Donna Cardamone for her comments on this text, and to Richard Wistreich for the English translation and fruitful discussion of the topic.

2 "That natural musical instinct, with which it appears that heaven has endowed every Neapolitan, almost every one adds art to nature: and thus day and night, at times with voices, at times with instruments, diverse harmonies of heavenly sweemess are heard in various places ... : Benedetto di Falco, Antichità di Napoli e del suo amenissimo distretto, Naples, 1535; translation: Donna G. Cardamone, The Canzone Villanesca alla Napolitana and Related Forms, 1537-1570 
This image was based mainly on a mythical past, the age of the magnificent Aragonese court of the fifteenth century, which had transformed Naples into one of the principal musical centres of Europe. The memory of Aragonese musical splendours continued long after the demise of the kingdom in 1503 and the start of the Spanish occupation. ${ }^{3}$ It seems as though the entertainments organised in the city in the early sixteenth century were almost designed to maintain the illusion that nothing had changed. A document that reinforces this is the anonymous romance La question de amor (whose first known editions were printed in Valencia 1513 and Salamanca in 1519), which recounts a series of grand entertainments organised in Naples in 1506, the year in which the new sovereign Ferdinand the Catholic visited the city. The whole romance is filled with descriptions of noble men and women singing and playing, above all, Spanish romances and villancicos. ${ }^{4}$ It is no coincidence that the first mention of the performance of villanellas coincides with the next visit of a Spanish sovereign to Naples - Charles V - between late 1535 and early 1536: »... Gruppi di musici gareggiavano l'un con l'altro nel cantare cose villanesche all'usanza di qua o cose de madrigali molto concertatamente ${ }^{5}$

(Ann Arbor, 1981), vol. 1, p. 105. »In the higher part of the realm of Italy is a country named the kingdom of Napolis ... The uplandish or country people of the which country have a certain kind of music, the which differeth from all others in Italy. And although in the composition thereof (they being but of three parts) there be faults and errors; yet for the pleasant strangeness of the trade of them, divers musicians have not only amended them and made them into four parts, but also divers other musicians, imitating of that music, have made of their like unto theirs: The Autobiography of Thomas Whythorne. Modern Spelling Edition, ed. James. M. Osborn (London, 1962), p. 148. "The country people [in Naples are] so jovial and addicted to music that the very husbandmen almost universally play on the guitar, singing and composing songs in praise of their sweethearts, and will commonly go to the field with their fiddle. They are merry, witty and genial, all of which I much attribute to the excellent quality of the air ...*: The Diary of John Evelyn, ed. Esmond S. de Beer (London, 1955), sub anno 1645. On the myth of "Napoli gentile« and the musical town see Michele Rak, Napoli gentile. La letteratura in >lingua napoletana nella cultura barocca (1596-1632) (Bologna, 1994). For the literary sources see also Elena Ferrari Barassi, »Costume e pratica musicale in Napoli al tempo di Giambattista Basile«, Rivista italiana di musicologia 2 (1967), pp. 74-110.

3 See Dinko Fabris, »El nacimiento del mito musical de Nápoles en la época de Fernando el Católico«, Nassarre 9 (1993), pp. 239-79; id., "Il compianto per il perduto splendore artistico musicale della corte Aragonese in un manoscritto napoletano del primo Cinquecento«, Trent'anni di ricerca musicologica. Studi in onore di F. Alberto Gallo, ed. Patrizia Dalla Vecchia and Donatella Restani (Rome, 1996), pp. 305-21.

4 Benedetto Croce, »Di un antico romanzo spagnuolo relativo alla storia di Napoli: la `Question de Amor «, Archivio Storico per le Propince Napoletane 19 (1894).

5 "Groups of musicians call out to each other by singing typical svillanellas or madrigals, all wonderfully concerted«: Letter from Naples on 23 January 1536 from Nicola Mattei to the Duke Federico of Mantua, quoted in Giuseppe Coniglio, "Note sulla società napoletana ai 
The novel song style was such a success, that barely a year later the first anonymous collection of villanellas for three voices was published, inaugurating a long and successful series of editions which was to continue with high intensity at least until $1570 .^{6}$ In contrast to the earlier villancico in Castille, the villanella acquired a clear political significance after the visit of Charles V. A style of song in the language of its people and representative of their national identity emerged just as Naples finally realised that it had definitively lost its independence. At the same time that complaints about the lost status of the capital were increasing, the villanella displayed the characteristic style of the celebrated improvvisatori of that Aragonese court. As Donna Cardamone says »the villanesca literature can be described as soloistic, a continuation of the unwritten tradition carried out by the citaredi or self-accompanying popular singer. $\ll^{7}$

The interest in the villanella which has developed over the past fifty years, and especially now, with the first attempts to reconstruct performances of this repertoire, has been dogged by a major misunderstanding. The traditional view is that the villanella is a spopular genre, which had its origins in the sixteenth century within the lowest social strata of the region of Naples and elsewhere in Italy. Over the past 25 years a group of scholars including Nino Pirrotta, Donna Cardamone and Howard Mayer Brown has demonstrated that the original creators, performers and consumers of the villanella in Naples and in the principal cities of Italy were, in fact, members of the nobility and never the "populace ${ }^{8}{ }^{8}$

tempi di Don Pietro da Toledo«, Studi in onore di Riccardo Filangieri (Naples, 1959), vol. 2, p. 360. - On Charles V in Naples see Gregorio Rosso, Historia delle cose di Napoli sotto l'Imperio di Carlo Quinto, cominciando dall'Anno 1526, per infino all'Anno 1537. Scritta per modo di Giornali (Naples, 1635); Ulisse Prota-Giurleo, "Musici napoletani del '500: Ferrante Sanseverino e il lamento di sDonna Sabellare, Partenope 2 (1961), pp. 293-305; id., "L'imperatore Carlo V a Napoli e a Roma 1535-1536«, id., Scritti inediti e rari (Naples, 1988), pp. 89-103.

6 Cardamone, The Canzone Villanesca ( $\mathrm{cf}$. fn. 2), vol. 1, passim; Concetta Assenza, La canzonetta dal 1570 al 1615 (Lucca, 1997), Introduction.

7 See Donna G. Cardamone, »The Debut of the canzone villanesca alla napolitana", Studi musicali 4 (1975), pp. 85-96, on the derivation of the early villanesca from the habits of improvisers; in addition: Cardamone, The Canzone Villanesca (cf. fn. 2), vol. 1, pp. 49sq., and id., "A Colorful Bouquet of Arie Napolitane«, Recercare 10 (1998), pp. 133-50, with reference to the previous tradition of citaredi in Naples.

8 Nino Pirrotta, Li Due Orfei: da Poliziano a Monteverdi (Turin, 1969); Howard Mayer Brown, "Petrarch in Naples: Notes on the Formation of Giaches de Wert's Style", Altro Polo. Essays on Italian Music in the Cinquecento, ed. Richard Charteris (Sidney, 1991), pp. 16-50; id., "Lasso in Naples and Rome: The Early Four-Parts Madrigals«, Liber Amicorum John Steele: A Musicological Tribute, ed. Warren Drake (Stuyvesant, NY, 1997), pp. 87-116; Cardamone, The Canzone Villanesca ( $\mathrm{cf}$. fn. 2), passim, and the essays quoted below. For Neapolitan noblemen performers of villanella, see Richard Wistreich, Giulio Cesare Brancaccio and Solo Bass Singing in Six- 


\section{VILLANESCHE}

\section{ALLA NAPOLITANAET}

Villotte bellifime, con altre Cans

zoni da cantare. Et vn Capis

tolo compoftoda vna Don

na, ad effempio a turte le

alcre, fcopre Pingratiru

dine de gl'huomini.

Opera bella \& di piacere, di nuouo pofta in luce.

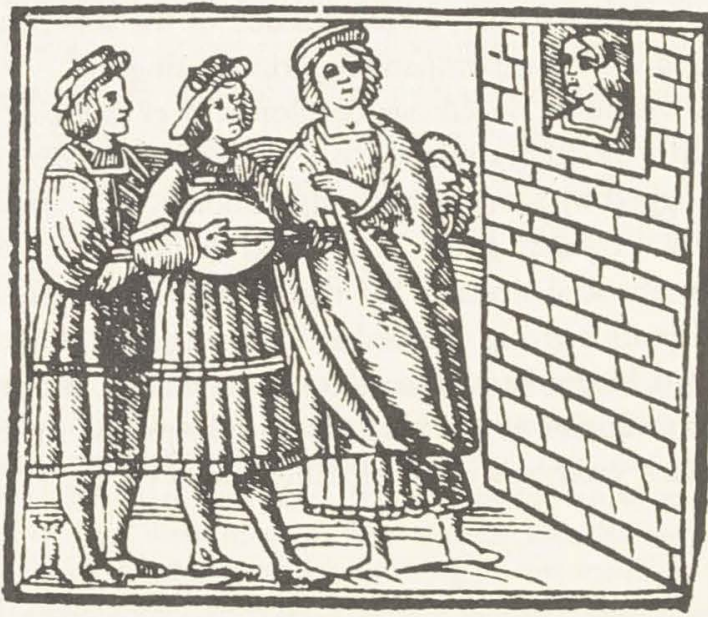

Figure 1: A typical performance of villanellas with voice and lute (see Cardamone, The Canzone Villanesca, cf. fn. 2, vol. 2, p. 280, pl. 29)

Immediately after the visit of Charles $\mathrm{V}$ and the associated birth of the villanella, the genre became the ssignatures of the extraordinary court located at the palace of the Prince of Salerno, Ferrante Sanseverino, which for at least a decade constituted a genuine opposition to the court of the Spanish viceroy, the powerful Pedro de Toledo. ${ }^{9}$ Nobles, letterati, actors and musicians (the latter coordinated

teenth Century Italy (Ph.D. diss. Royal Holloway College, University of London, 2002) (forthcoming) and my own essays on Fabrizio Dentice referred to below (cf. fn. 10).

9 In addition to the essays by Cardamone and Fabris already quoted, see also Cesare Corsi, "Le corte Sanseverino. Nuovi documenti sul mecenatismo musicale a Napoli e in Italia meridionale nella prima metà del Cinquecento", Fonti d'archivio per la storia della musica e dello spettacolo a Napoli tra XVI e XVIII secolo, ed. Paologiovanni Maione (Naples, 2001), p. 36. 
by the famous singer, lutenist and music theorist, the cavaliere Luigi Dentice ${ }^{10}$ ) congregated around the prince, who was regarded as the last of the Aragonese kings (a fact which would eventually cause his downfall). In the course of their many wanderings through Italy and the rest of Europe, particularly in France in the 1540s, members of the Sanseverino court were also primarily responsible for the dissemination of the villanella beyond Naples. In 1552, as a consequence of the Neapolitan revolution in 1547, the Prince of Salerno was exiled for defecting to France and his wife Isabella was allowed to remain in Naples confined to the Castelnuovo. Their fate, which also signalled the fading of the dream of an artistic revival in Naples, gave rise to one particular type of villanella, a lament in the form of a narrative parting song on the theme of aristocratic exile and the unhappy vagaries of human fortune - a subject which would indeed seem unlikely in the context of 'popular peasants' music ${ }^{11}$

After the downfall of the Prince of Salerno, the musicians of his court were also forced to flee, and most of them went to Rome. Here, exiled performers such as Luigi Dentice and his son, Fabrizio (who was also a famous lutenist $\mathrm{t}^{12}$ ) probably crossed paths with composers of the calibre of Orlando di Lasso to recreate performances of villanellas, which in earlier years had echoed through the Sanseverino palace in Naples. ${ }^{13}$ From this point, around 1555 , the villanella definitively broke free from the confines of the Kingdom of Naples and became a phenomenon with a national dispersal, becoming the latest fashion in Tuscany

10 Ferrante Sanseverino and his court, including Luigi Dentice, were travelling around Europe and in particular in France between 1540 and 1545, the year in which they returned to Naples and began there theatrical activities. Like his prince, Luigi Dentice continued to receive a pension from the King of France in the years 1559-60. See Émile Picot, Les Italiens en France au XVIe siècle (Bordeaux, 1901-18, reprint Manziana, 1995), p. 183; Da Napoli a Parma: itinerari di un musicista aristocratico. Opere vocali di Fabrizio Dentice (1530 ca-1581), ed. Dinko Fabris (Milan, 1998), p. 56.

11 The chordal or aria-like style typical of the villanella is clearly reflected in the exile-songs "Come thaggio lassata «, also called Lamento del Principe of Salerno, that Cardamone has suggested as being composed by Luigi (or Fabrizio) Dentice at the request of the Prince Sanseverino. See Donna G. Cardamone, "The Prince of Salemo and the Dynamics of Oral Transmission in Songs of Political Exile«, Acta musicologica 67 (1995), pp. 77-108; id., "The Prince and Princess of Salerno and the Spanish Viceroy: Popular Songs of Exile«, Revista de musicologia 16 (1993), pp. 2531-41.

12 On Fabrizio Dentice see Dinko Fabris, »Vita e opere di Fabrizio Dentice, nobile napoletano, compositore del secondo Cinquecento«, Studi Musicali 21 (1992), pp. 61-113; id., Da Napoli (f. fn. 10), Introduction; Neapolitan Lute Music. Recent Researches in the Music of the Renaissance, ed. John Griffiths and Dinko Fabris (Madison, 2003, forthcoming), Introduction.

13 See Brown, Lasso in Naples (cf. fn. 8), Donna Cardamone's essays quoted in fn. 11 and the more recent contribution by the same: "Orlando di Lasso et al: A New Reading of the Roman Villanella Book (1555) «, paper read at the $17^{\text {th }}$ International Congress of the IMS (Leuven 2002). 
as well as in Venice. In 1559 a group of noble Neapolitan performers, certainly including Fabrizio Dentice, performed villanellas for the first time in Spain, in the presence of Philip II. ${ }^{14}$ In the same years reprints of villanellas increased steadily, both within and beyond Italy, an indication that we are now dealing with a major commercial success story. Yet the international spread of these compositions radically changed their original significance as the political songs of a >lost $\times$ Neapolitan society, preserving only the exotic aspects of the language and other references to aspects of the national character, reflecting a prevailing curiosity in other parts of the world about all things different.

Contrary to what the great number of polyphonic villanellas published in part books for three or four voices would lead us to believe, the most widespread performance style for these compositions was solo voice accompanied by a lute or other stringed instrument. In fact, the great majority of sources refer to musicians who sang alone to their own accompaniment, nearly all of whom were from Naples or had been educated there. The most famous example is that of Orlando di Lasso performing the villanella »Chi passa« in Munich during the wedding celebrations of 1568 which was related by the famous actor, singer and composer of villanellas, Massimo Troiano, himself a Neapolitan. ${ }^{15}$ There is an apparent contradiction between recent notions of villanella performance practice and that which is revealed in the majority of surviving sources, principally literary and iconographical, of a song improvised to the lute or similar instrument, and which is further confirmed by the lack of musical sources of villanelle intabulated for voice and lute or another accompanying instrument in the same period.

In fact we need to wait until after 1570 to find books of villanellas published with lute intabulation together with notation of a part for solo vocal performance. But it is important to remember that in Italy vocal music intabulated in score for voice and lute - apart from the early examples by Franciscus Bossinen-

14 »The court of Madrid hosted a group of Neapolitan virtuosi, who agreed to perform new, never-before heard madrigals and villanellas for His Majesty every day for a full month; and so they did, with various and sundry instruments ...* ("Capitorno in quel tempo in Madrid una muta di virtuosi Napoletani, che si obbligorno far sentire a S. Maestà ogni giomo madrigali, \& villanelle nove non più udite per un mese di lungo, \& così fecero, con varii \& diversi instrumenti ... «): Vincenzo Cervio, Il trinciante (Rome, 1593, reprint Sala Bolognese, 1980), p. 102, quoted in Fabris, Vita e opere (cf. fn. 12), p. 99.

15 See Massimo Troiano, Discorsi delli triomfi ..., giostre, apparati, é delle cose piu notabile fatte nelle sontuose Nozze, dell Illustrissimo er Eccelentißimo Signor Duca Guglielmo ... nell'anno 1568... Di Massimo Trojano da Napoli, Musico dell Illustrissimo ed Eccellentissimo Signor Duca di Baviera (Munich, 1568), modified edition: Dialoghi di Massimo Troiano: Ne' quali si narrano le cose piu notabili fatte nelle Nozze ... (Venice, 1569), p. 149, reprint and translation: Die Münchner Fürstenhochzeit von 1568. Studien zur Landes- und Sozialgeschichte der Musik 4, ed. Horst Leuchtmann (Munich, 1980), p. 313. 
sis, Bartolomeo Tromboncino and Marchetto Cara (1509-1520) - anyway only began to appear in printed sources as well in manuscripts around 1570 . We know of a total of about 100 printed collections containing Italian lute intabulation published between the end of the fifteenth and the middle of the seventeenth centuries, which is about the same number as the total of lute manuscripts from the same period, and of these, around twenty per cent of the volumes published after 1570 contain intabulated vocal music. Madrigals, naturally enough, are the most prevalent, but in second place come villanellas, which shows one of the most successful genres of the century also being represented in this form of an intabulated edition. ${ }^{16}$ In the period after 1570 (and here considering only the repertoire related to performance with lute) various types of notational forms coexist simultaneously, corresponding to the diverse significances of the villanella. It is possible that the first author who attempted to elevate the villanella genre to the status of the madrigal was Gaspare Fiorino, who was both a composer and poet. In 1571 he engaged a professional lutenist, the still enigmatic Francesco de Parise, to arrange and transcribe his pieces into lute intabulation. ${ }^{17}$

In the first book of villanellas (Il primo libro delle Napolitane che si cantano et sonano in Leuto) by the blind lutenist Giacomo Gorzanis, published in the previous year (1570), all the intabulations were made by the composer himself. This certainly reflects the traditional practice of improvising villanellas to the lute, based on standard forms. ${ }^{18}$ His realisations are, in fact, faithful intabulations of the original three vocal parts in score, preserving all the parallel fifths and other particularly improvisational and instrumental characteristics. It can be no coin-

16 See the statistics related in Dinko Fabris, "La diffusione della musica vocale nelle intavolature per liuto dell'epoca di Monteverdi«, Intorno a Monteverdi, ed. Maria Caraci Vela and Rodobaldo Tibaldi (Lucca, 1999), pp. 497-509; Assenza, La canzonetta (cf. fn. 6), pp. 23-102; Marco Giuliani, Catalogo delle villanelle alla napolitana, canzonette e forme affini del '500 e del '600 (desunte dalla bibliografia del vecchio e nuovo Vogel) (Trent, 1995).

17 La Nobiltad di Roma. Versi in lode di cento gentildonne romane, et le villanelle a tre voci di Gasparo Fiorino della città di Rassano, Musico dell'Illustrissimo of Reverendissimo Signore Cardinale di Ferrara. Intavolate dal Magnifico M. Francesco di Parise, Musico eccellentisimo in Roma (Venice, 1571; BR 1571 4 ), BR: Howard Mayer Brown, Instrumental Music Printed before 1600. A Bibliography (Cambridge, Mass., 1965). On Fiorino and his role in the development of the villanella see Villanella Napolitana Canzonetta. Relazioni tra Gasparo Fiorino, compositori calabresi e scuole italiane del Cinquecento. Atti del Convegno Internazionale di Studi, Arcapacata di Rende, Rossano Calabro ... 1994, ed. Maria Paola Borsetta and Annunziato Pugliese (Vibo Valentia, 1999). See also the Introduction to the forthcoming book: Elio Durante and Anna Martellotti, Le Canzonette a tre voci di Giuliano Paratico [Brescia, 1588] un amico bresciano di Angelo Grillo, (Florence, 2002).

18 Il primo libro di napolitane che si cantano et sonano in leuto nuovamente composte da Jacomo Gorzanis leutanista cittadino della magnifica città di Trieste (Venice, 1570; BR 1570 1 ). On this author see a thesis in progress by Alenka Bagaric at the University of Ljubljana (2003). 
cidence that in the Biblioteca Nazionale in Florence, there is a collection containing a copy of each of the volumes by Fiorino and Gorzanis bound together with a third, the almost contemporary book of villanellas, $I l$ Turturino, by Cornelio Antonelli which was published in $1570 .{ }^{19}$

Unlike the refined Fiorino, who left the intabulation of his villanellas to a "musico eccellentissimo in Roma«, Antonelli stated that he had collected compositions from various composers which he had »accommodate sul leutok himself. Of these three early examples of intabulators of villanellas, only Gorzanis could boast of having composed and arranged the intabulations on the lute himself, following a practice of instrumental rather than vocal improvisation (»queste mie Napolitane, che si suonano, et si cantano»).

The renowned festivities in Munich in 1568 and those in Vienna in 1571 were crucial moments of arrival for the "early villanella and for its transformation and diffusion throughout Europe with a potential that has only been recognised in recent years: when performed as a solo for voice and lute, these villanellas were nothing less than the earliest Italian form of "proto-monody«, anticipating the Florentine experiments by a few decades (for Spanish »protomonodies « see John Griffiths' article in this volume). I have mentioned Munich and Vienna because at these two festive occasions many musicians were present who had connections with Naples and with the first phase of the villanella which I traced earlier. The celebrations in Munich, where, amongst others, Orlando di Lasso was to be heard singing the villanella repertoire, were recorded in the above mentioned diary of the Neapolitan composer Massimo Troiano, who had previously been in the service of the Spanish governor of Milan and had published at least two books of napolitane. ${ }^{20}$ At the celebrations in Vienna,

19 Il Turturino. Il primo libro delle napolitane ariose da cantare et sonare nel leuto composte da diversi eccellentissimi musici, o nopamente per il Rev.P.F. Cornelio Antonelli de Rimino detto il Turturino, acomodate sul leuto (Venice, 1570; BR 1570 ). No doubt that the three books by Gorzanis, Antonelli and Fiorino were part of an editorial project by Scotto, similar to the series of lute books published in the 1540's.

20 Di Massimo Troiano di Corduba da Napoli il primo et secondo libro delle canzomi alla napolitana, a tre voci (Venice, 1568; NV 2755); Di Massimo Troiano da Napoli il terzo libro delle sue rime e canzoni alla napolitana a tre voci colla Battaglia della gatta e la cornachia con una Amascherata alla turchesca a cinque voci et una Moresca novamente fatte et date in luce (Venice, 1567, reprint 1568; NV 2756-7); Di Massimo Troiano da Napoli musico dellillustriss. Et eccellentiss. Sig. duca di Baviera, il quarto libro delle sue rime, et canzoni alla napolitana a tre voci. Con un'aria alla spagnola a quattro voci. Nopamente posto in luce (Venice, 1569; NV 1758). The latter volume is dedicated to »D. Giovanni Manriq. Cameriero di Massimiliano Secondo, imperator romano«: "Quando alli giomi adietro ... io fui in Vienna, a donare a sua sacra maestà cesarea, il libro ch'io feci nelle virtuose nozze dell'Illustriss. Duca Guglielmo di Baviera... queste poche villanelle nate in Germa- 
other southern musicians took part, such as Giacomo Gorzanis, who wrote a villanella for the occasion (dedicated to the singer Marta) and which subsequently appeared in his second book of napolitane, published in 1571 and dedicated to the Austrian Archduke Charles. ${ }^{21}$

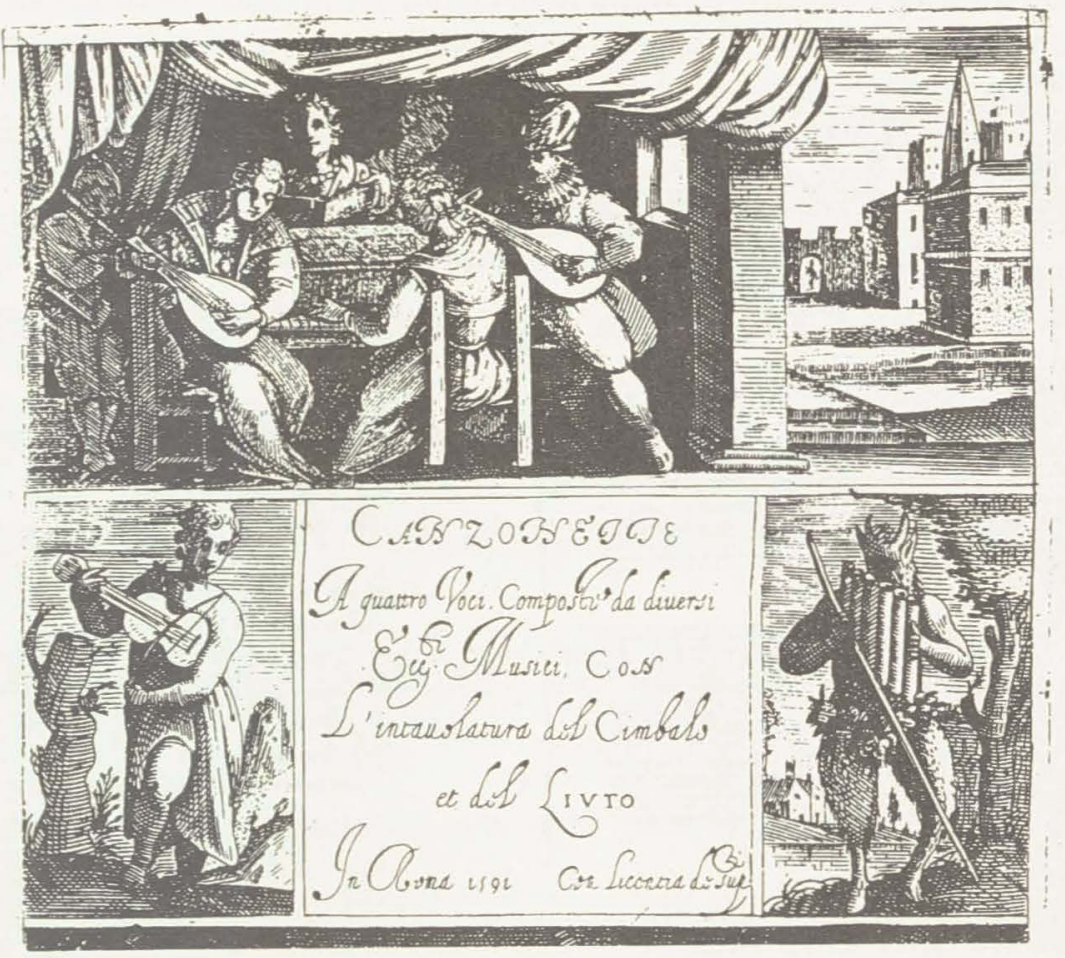

Figure 2: Simone Verovio, Canzonette a quattro voci ... con l'intavolatura del cimbalo e del liuto (Rome, 1592), frontispiece: on the top a typical performance of canzonettas with voices and instruments

After 1570 the majority of books of villanellas and canzonettas published in Italy began to appear with lute intabulations alongside the parts for the voices.

nia ...*. NV: Emil Vogel, Alfred Einstein, François Lesure, Claudio Sartori, Il Nuovo Vogel. Bibliografia della musica italiana pocale profana pubblicata dal 1500-1700, 3 vols. (Pomezia, 1977).

21 See Robert Lindell, "Marta gentile che 'I cor m'ba morto. Eine unbekannte Kammermusikerin am Hof Maximilians II.«, Musicologica Austriaca 7 (1987), pp. 59-68. On 1571 festivals: id., "The Wedding of Archduke Charles and Maria of Baviera in 1571 «, Early Music 17 (1990), pp. 25369 , and $» \mathrm{La}$ villanella oltremontana: esempi dalla corte imperialek, in Borsetta, Villanella $\mathrm{Na}$ politana Canzonetta (cf. fn. 17), pp. 153-62 (with transcription of Gorzanis's villanella »Marta gentilk). 
But this reveals more about the commercial fortunes of such books than anything precise about possible performance practices, which surely differed from those of the improvisers of the »early villanella«.

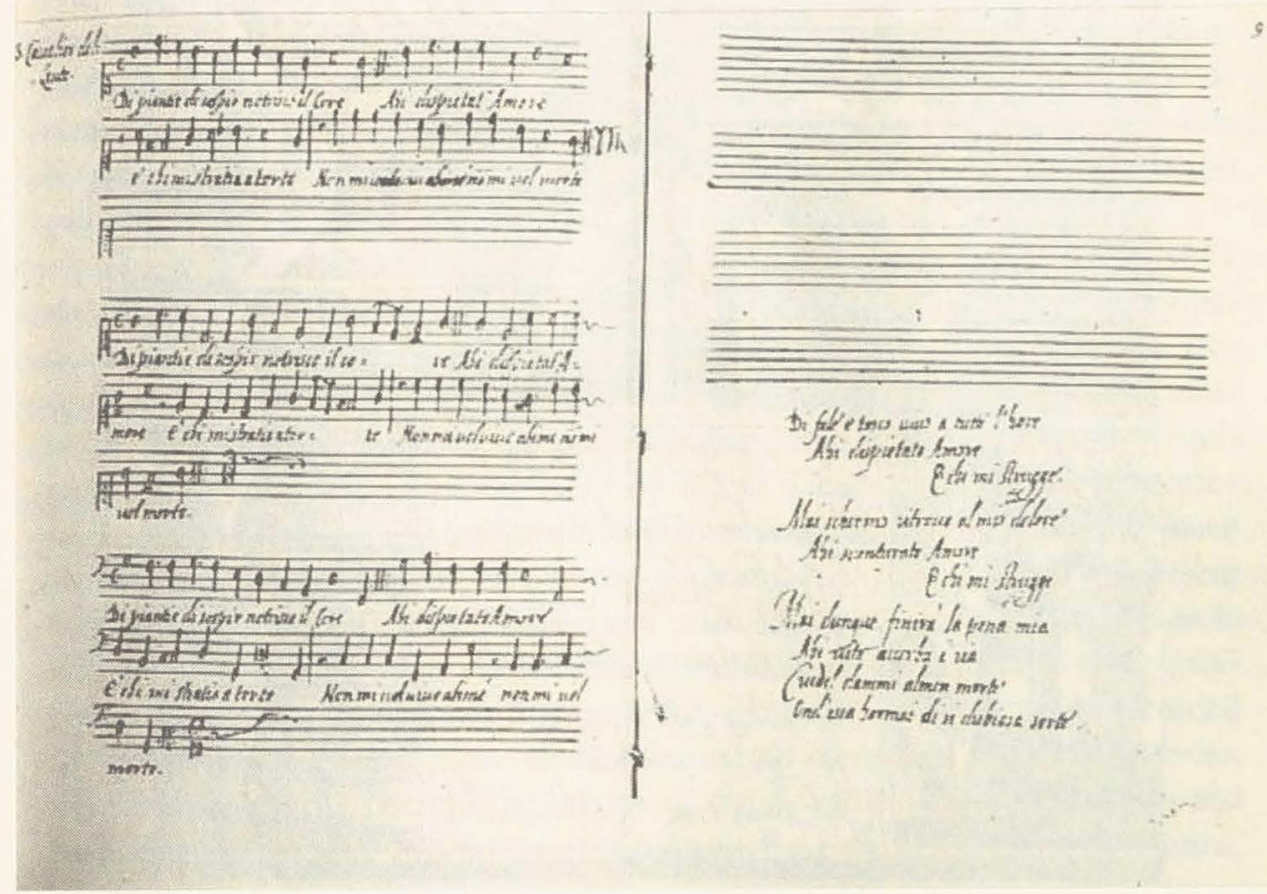

Figure 3: Libro di Villanelle »Monaldi Brancaleonis et suorum amicorum « (I-MOe, MS a.k.6.31): "Di pianti e di sospir« by "Cavaliere del Leuto»

On the other hand, such practices are surely reflected in the few but precious surviving Italian manuscript sources of villanellas with intabulation. The oldest appears to be the MS a.k.6.31 in the Biblioteca Estense in Modena, the Libro di Villanelle of "Monaldi Brancaleonis et suorum amicorum", a collection copied in northern Italy at the end of the sixteenth century in a format very similar to the contemporary editions published by Paolo Bellasio, Lelio Bertani or Simone Verovio: a score in choirbook that includes the three vocal parts and a lute in- 
tabulation. Unfortunately, with the exception of a single complete piece, all the pages intended for the lute are empty, save for bare staves. ${ }^{22}$

The second source that I wish to cite is a manuscript that has now disappeared but which is preserved in a complete eighteenth-century transcription that also includes notation for the modern guitar; the manuscript belonged to Oscar Chilesotti and is now in Bassano del Grappa. ${ }^{23}$ This source offers examples of villanella patterns set as dances. ${ }^{24}$

14

Nr. 14. Villanelle.

1. (Pag.28 dell' originale).
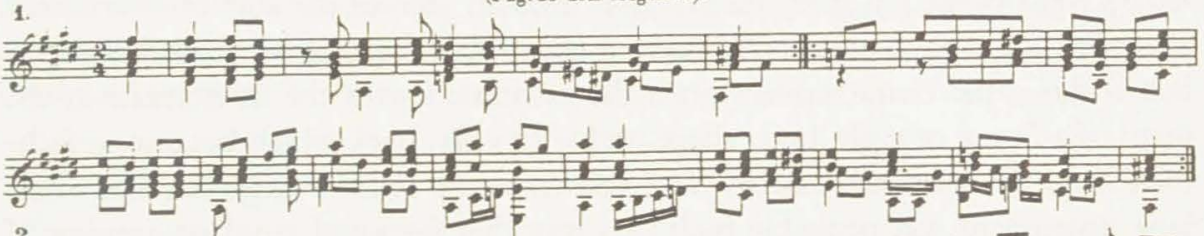

2.
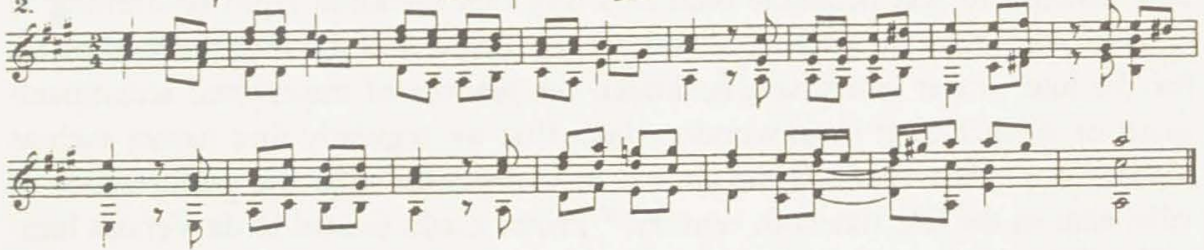

Figure 4: Chilesotti Lute Book, Villanella, in the guitar transcription ed. Oscar Chilesotti (Lipsia, 1890), p. 14

22 On this manuscript, which contains also one villanella by $m S$. Cavalier del Leutor ( $m$ Di pianti e di sospir notrisco il core«, text by Giuliano Paratico, music possibly by Fabrizio Dentice), see Fabris, Da Napoli (cf. fn. 10), p. 51. For other Italian lute manuscripts and prints including villanellas (Lucca, Biblioteca Governativa, 774; some mss. in the Biblioteca Riccardiana, Florence: 2971, 2977; Fallamero Lutebook 1584 etc.) see Cardamone, The Canzone Villanesca (cf. fn. 2), vol. 1, pp. 262-3. In addition: Orazio Vecchi, The Four-Voice Canzonettas with Original Texts and Contrafucta by Valentin Haussmann and others. Recent Researches in the Music of the Renaissance 92-3, ed. Ruth I. De Ford, 2 vols. (Madison, 1993), Introduction and p. 9 (Table 1: Intabulations of Vecchi Canzonettas).

23 Da un codice Lauten-Buch del Cinquecento. Trascrizioni in notazione moderna di Oscar Chilesotti (Lipsia, 1890, reprint Bologna, 1968).

24 The only direct mention of »quel grazioso ballo / detto la villanella, / cosa certo assai bella « is in Giovan Battista Del Tufo, Ritratto o Modello delle grandezze, delitie e meraviglie della nobilissima Città di Napoli: testo inedito del Cinquecento [1588], ed. Calogero Tagliareni (Naples, 1959), quoted also in Gennaro Maria Monti, Le villanelle alla napoletana e lantica lirica dialettale a Napoli (Città di Castello, 1925), p. 4, with other exemples of Ballo della villanella. 
The third source is the well known "Bottegari Lute Book", a manuscript now in the Biblioteca Estense in Modena (MS C.311) but of Florentine origin, compiled sometime after 1574. In this precious collection we find numerous examples of "proto-monody«, including villanellas called aeri with mensural notation for a solo voice and an intabulation of the song that constitutes a true basso contimuo. Amongst the many examples of the genre copied into the Bottegari manuscript are the two villanelle-aeri by Fabrizio Dentice, "Empio cor* and $»$ Amor che deggio far ${ }^{25}$

I have stressed the improvised nature of the lute accompaniments in the solo vocal performance of the "early villanella«. A recent study of the chitarra italiana by Renato Meucci gives for the first time an idea of the sort of instrument preferred for such a practice. ${ }^{26}$ There was in fact a type of lute called chitarra, but without the characteristics normally associated with the instrument in the form of a figure of eight body shape and with a flat back which became so fashionable in the sixteenth century, and known as the chitarra spagnola. The "Italian instrument was probably built in a way that favoured rapid strumming of chords rather than the playing of counterpoint typical of the more refined music for the lute, and it could have facilitated the practice of improvised accompaniment of villanellas. It is no wonder, then, that we regularly find names such as chitarrino or chitarrino alla napoletana in connection with the performance of villanellas in the late sixteenth century. ${ }^{27}$ Prince Carlo Gesualdo da Venosa himself and the aristocratic musicians in his circle were, according to Scipione Cerreto, excellent performers on the chitarrino. ${ }^{28}$

The experiments in solo song made by the Neapolitans well before 1570 helped foster the fashion for monody accompanied by chordal instruments such as the lute, guitar and later, the chitarrone. Nino Pirrotta, Howard Mayer Brown and more recently, John Hill, have constructed a new and innovative theory proposing the existence of a sschool of cantar recitando in Naples not

25 Modern edition of Dentice's aeri in Fabris, Da Napoli (cf. fn. 10), pp. $71-6$ (see also Introduction and a description of the source at p. 50).

26 Renato Meucci, "Da chitarra italiana a chitarrone: una nuova interpretazione«, Enrico Radesca di Foggia e il suo tempo. Atti del convegno di studi, Foggia ... 2000, ed. Francesca Seller (Lucca, 2001), pp. 37-57.

27 On the existance of other instruments named »alla napoletana« see the earliest inventory of Neapolitan lutemakers published by Francesco Nocerino, "La bottega dei sviolari< napoletani Albanese e Matino in un inventario inedito del 1578«, Liuteria Musica e Cultura [20] (19992000), pp. 3-9.

28 Scipione Cerreto, Della prattica musica vocale, et strumentale (Naples, 1601, reprint Bologna, 1969), pp. 157sq. 
long after the mid-sixteenth century ${ }^{29}$ that anticipated the Florentine experiments of Giulio Caccini and others, based on models for improvising songs derived from that of the villanella, and which became known as aere, for one voice accompanied by lute or chitarrino. From Naples these aeri (that is, "villanella-monodies") initially became established in Rome, as a first phase, where the presence of virtuoso Neapolitan musicians consolidated a style of singing considered as "alla napoletana and from which the romanesca was subsequently derived. ${ }^{30}$ It was in this environment of experimentation that Caccini (called "Romano«) received his early musical education. Because Caccini left Rome for Florence while he was still very young, he did not have the opportunity to be directly involved in the ensuing stylistic evolution of the "maniera di cantare " to the lute, theorbo or guitar which flourished mainly thanks to the patronage of Cardinal Montalto. ${ }^{31}$

29 See John Walter Hill, Roman Monody, Cantata and Opera from the Circles around Cardinal Montalto (Oxford, 1997), vol. 1, pp. 57-139. Hill's theory follows the pioneers: Pirrotta, Li due Orfei (cf. fn. 8); Howard Mayer Brown, »The Geography of Florentine Monody: Caccini at Home and Abroad«, Early Music 9 (1981), pp. 147-68; id., Petrarch in Naples (cf. fn. 8); id., Lasso in Naples (cf. fn. 8); Cardamone, The Canzone Villanesca (cf. fn. 2); id., The Prince and Princess (cf. fn. 11); id., The Prince of Salemo (cf. fn. 11); id., »Orlando di Lasso and ProFrench Factions in Romex, Orlandus Lassus and his Time: Colloquium Proceedings, Antwerpen ... 1994. Yearbook of the Alamire Foundation 1, ed. Ignace Bossuyt (Peer, 1995), pp. 23-47.

30 See Hill, ibid., vol. 1, pp. 180-234, and Tim Carter, "Giulio Caccini: New Facts, New Music«, Studi Musicali 16 (1987), pp. 13-31.

31 Hill, ibid., vol. 1, pp. 110-22, and my review of Hill's book published in the Journal of the Royal Musical Association 125 (2000), pp. 287-99. 